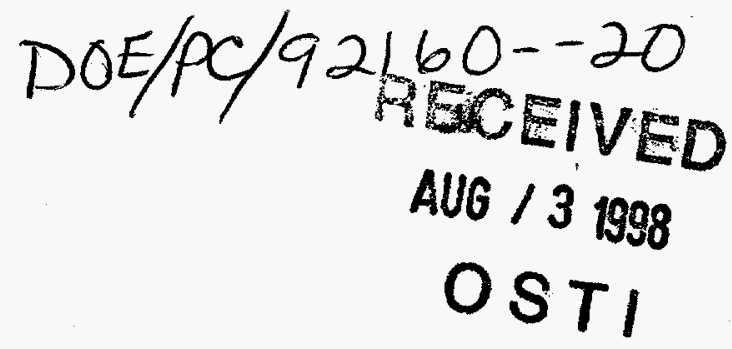

\title{
Engineering Development of Advanced Coal-Fired Low-Emissions Boiler Systems
}

\author{
Quarterly Report \\ April 1 - June 30, 1997
}

Work Performed Under Contract No.: DE-AC22-92PC92160

For

U.S. Department of Energy

Office of Fossil Energy

Federal Energy Technology Center

P.O. Box 880

Morgantown, West Virginia 26507-0880

DASTAMUTION OF THS DOCUMENT IS UNLMATED

Babcock \& Wilcox Company

1562 Beeson Street

Alliance, Ohio 44601 


\section{Disclaimer}

This report was prepared as an account of work sponsored by an agency of the United States Government. Neither the United States Government nor any agency thereof, nor any of their employees, makes any warranty, express or implied, or assumes any legal liability or responsibility for the accuracy, completeness, or usefulness of any information, apparatus, product, or process disclosed, or represents that its use would not infringe privately owned rights. Reference herein to any specific commercial product, process, or service by trade name, trademark, manufacturer, or otherwise does not necessarily constitute or imply its endorsement, recommendation, or favoring by the United States Government or any agency thereof. The views and opinions of authors expressed herein do not necessarily state or reflect those of the United States Government or any agency thereof. 


\section{DISCLAIMER}

Portions of this document may be illegible in electronic image products. Images are produced from the best available original document. 
"This report was prepared by Babcock \& Wilcox pursuant to a contract partially funded by the U. S. Department of Energy and neither Babcock \& Wilcox, nor any of its subcontractors nor the U. S. Department of Energy, nor any person acting on behalf of either:

(a) makes any warranty or representation, expressed or implied, with respect to the accuracy, completeness, or usefulness of information contained in this report, or that the use of any information, apparatus, method, or process disclosed in this report may not infringe privately owned rights; or

(b) assumes any liabilities with respect to the use of, or for damages resulting from the use of, any information, apparatus, method or process disclosed in this report.

Reference herein to any specific commercial product, process, or service by trade name, trademark, manufacturer, or otherwise, does not necessarily constitute or imply its endorsement, recommendation, or favoring by the U. S. Department of Energy. The view and opinions of authors expressed herein do not necessarily state or reflect those of the U. S. Department of Energy." 


\section{Project Management}

\section{I.1 Summary of Activities}

\section{I.1.1 Period of April 1997 through June 1997}

The detailed test and operations plan to operate, demonstrate, and evaluate the POC test facility was completed. The test plan was written to meet the objectives as set forth in the SOW. The POC test plan is being incorporated into the Phase III final report. The POC schedule and Phase IV cost estimate were also completed.

The Phase II final report draft was completed. Topical reports addressing the areas identified in the report outlines are essentially completed. A draft version of the final report was distributed for internal review. Comments received during the internal review are being incorporated into the final report.

Work on the Phase III final report continued. Suggestions received from an internal review are being incorporated into the final report.

\section{L.1.1 Technical Papers Submitted or Presented}

Two papers were submitted for inclusion in the 1997 International Joint Power Generation Conference. The first paper, entitled, "B\&W's Advanced Coal-Fired Low-Emission Boiler System Commercial Generating Unit Design and Proof-of-Concept Demonstration, "gives an overview. of B\&W's entire LEBS design. The second paper, entitled, "Status and Demonstration of the B\&W DRB-4Z ${ }^{\mathrm{TM}}$ Burner Developed for B\&W's Advanced Coal-Fired Low-Emission Boiler System," focuses on the testing of the DRB- $4 Z^{\mathrm{MM}}$ burner. The papers will be presented in November.

\section{I.1.2 Phase IV Funding}

Efforts continue to develop support in North Dakota with hopes of obtaining funding. Utility contacts are in progress to identify and obtain tailored collaboration funds to support Phase IV where available. 


\section{NO $\quad$ Subsystem}

The goal of the $\mathrm{NO}_{\mathrm{x}}$ Subsystem is to achieve continuous operation of the Low-Emissions Boiler System (LEBS) at $\mathrm{NO}_{x}$ emissions at or below $0.20 \mathrm{lb} / \mathrm{MBtu}$ through combustion techniques only, with a further target of $0.1 \mathrm{lb} \mathrm{NO} / \mathrm{MBtu}$ using supplementary advanced flue gas cleanup technologies if necessary. These goals places practical constraints that must be considered on the $\mathrm{NO}_{x}$ Subsystem design. Not only must the boiler be designed to achieve time-temperature mixing histories that minimize $\mathrm{NO}_{\mathrm{x}}$, but it must also be designed to operate that way throughout its working lifetime. Therefore, $\mathrm{NO}_{\mathrm{x}}$ minimization strategies must be integrated into the control systems for every boiler component from the pulverizers to the stack. Furthermore, these goals must be met without increases in carbon loss and $\mathrm{CO}$ emissions from the levels achieved with current low-NO $\mathrm{NO}_{\mathrm{x}}$ combustion systems. Therefore, the $\mathrm{NO}_{\mathrm{x}}$ Subsystem requires not only sound mechanical designs of burners, furnace surface, and staging air/fuel injectors, but also sensors and software to allow control of their operation. Through engineering analysis, experimental testing, and numerical modeling in Phase $\mathrm{I}$, an advanced low-NO The progress of these activities is presented in this report.

\section{II.1 Summary of Activities}

\section{II.1.1 Period of April 1997 through June 1997}

Work on the final reports is in full swing. Drafts of all-Phase II and Phase III final reports were completed for internal review by month's end.

\section{I.2 Key Accomplishments}

\section{II.2.1 Final Reports}

All contributions to the final reports have been drafted for internal $r$ review. Topical reports addressing the areas identified in the report outlines and the Design Deficiency table from Phase I are essentially completed.

\section{II.2.2 POC Test Plan}

The detailed test and operations plan to operate, demonstrate, and evaluate the POC test facility was completed. The test plan was written to meet the objectives set forth in the SOW. The POC test plan is being incorporated into the Phase III Final Report. 


\section{III. $\mathrm{SO}_{2} /$ Particulate/Air Toxics/Solid By-Product Subsystem}

The scope of the $\mathrm{SO}_{2}$ subsystem comprises the control of $\mathrm{SO}_{2}$, particulate matter, hazardous air pollutants (commonly called "air toxics"), and solid byproducts from the $B \& W$ LEBS plant. The specific minimum performance requirements for the $\mathrm{SO}_{2}$ subsystem are:

- $\mathrm{SO}_{\mathrm{x}}$ - Less than $0.20 \mathrm{lb}\left(\mathrm{SO}_{2}\right.$ equivalent)/MBtu for coals with sulfur levels of $3 \mathrm{lb}$ of sulfur per MBtu and no more than 0.067 times the sulfur content (Ib/MBtu) for coals with less than $3 \mathrm{lb}$ of sulfur per MBtu.

- Particulate - Less than $0.015 \mathrm{lb}$ particulate/MBtu

- Potential to comply with possible emissions control regulations for targeted air toxics.

- Produce environmentally benign solid byproduct.

- Integrate with other plant subsystems to yield optimal overall performance and cost.

In addition, the following performance targets have been established:

- $\mathrm{SO}_{\mathrm{x}}$ - Less than $0.10 \mathrm{lb}\left(\mathrm{SO}_{2}\right.$ equivalent $) / \mathrm{MBtu}$ for coals with sulfur levels of $3 \mathrm{lb}$ of sulfur per MBtu and no more than 0.0333 times the sulfur content (Ib/MBtu) for coals with less than $3 \mathrm{lb}$ of sulfur per MBtu.

- Particulate - Less than $0.01 \mathrm{lb}$ particulate/MBtu (B\&W plans to achieve $0.005 \mathrm{lb} / \mathrm{MBtu}$ )

On the basis of the results compiled during the concept selection process completed in Phase I, the Limestone Injection Dry Scrubbing (LIDS) process was selected for further development and evaluation in B\&W's LEBS project. The LIDS process is a cost-effective integration of three commercially proven flue gas cleanup technologies: furnace limestone injection, dry scrubbing, and pulse-jet fabric filtration. As a result of Phase I testing, the initial LIDS process was enhanced by the addition of a particulate collector before the dry scrubber and the new process was named E-LIDSTM. Through engineering analysis, experimental testing, and numerical modeling, an E-LIDSTM process is being developed that is capable of ultra-high $\mathrm{SO}_{2}$ removal and superior particulate control while addressing the potential issues of air toxic emissions and solid byproduct utilization. The progress of the E-LIDSTM activities follows.

\section{III.1 Summary of Activities}

\section{III.1.1 Period of April 1997 through June 1997}

Drafts of all Phase II and Phase III final reports were completed for internal review by month's end. 


\section{II.2 Key Accomplishments}

\section{III.2.1 Final Reports}

All contributions to the final reports were drafted for internal $\mathrm{r}$ review. Topical reports addressing the areas identified in the report outlines and the Design Deficiency table from Phase I are essentially completed.

\section{III.2.2 POC Test Plan}

The detailed test and operations plan to operate, demonstrate, and evaluate the POC test facility was completed. The test plan was written to meet the objectives set forth in the SOW. The POC test plan is being incorporated into the Phase III Final Report. 


\section{Boiler Subsystem}

At the heart of the LEBS is the boiler. Within this advanced B\&W boiler, all of the low emission technologies are integrated. To meet the net plant efficiency goal of $42 \%$, the boiler must be designed not only to achieve the proper conditions for low $\mathrm{NO}_{\mathrm{x}}$ combustion with air staging and accommodate the in-furnace injection of the limestone for the LIDS process, but it must also efficiently capture the heat to produce high temperature steam at well above critical pressure. The steam conditions selected for the boiler are $4500 \mathrm{psi}, 1100^{\circ} \mathrm{F} / 1100^{\circ} \mathrm{F} / 1100^{\circ} \mathrm{F}$.

Since the steam-side pressure and main and reheat steam temperatures are higher than conventional cycles and operation of low $\mathrm{NO}_{\mathrm{x}}$ burners creates sub-stoichiometric conditions in portions the furnace, additional challenges are presented. Higher alloy materials must be used in the outlet portions of the superheater and reheater banks to obtain acceptable surface metal temperatures. In addition, materials must be selected that will resist corrosion since the surface of these outlet tubes will operate at temperatures which will allow the coal ash to remain molten on their surfaces. Consideration must also be given to furnace wall corrosion in the combustion zone. Thus, boiler design work has been identified to address the integration of the $\mathrm{NO}_{\mathrm{x}}$ and $\mathrm{SO}_{2}$ subsystems while applying B\&W's advanced supercritical boiler technology.

\section{IV.1 Summary of Activities}

\section{IV.1.1 Period of April 1997 through June 1997}

All design, drafting and cost estimating work was completed. Essentially all of the Phase III Volume 2 report has been drafted for internal reviews:

\section{IV.2 Key Accomplishments}

\section{IV.2.1 CGU Boiler Development}

Activities this quarter centered around completion of the CGU boiler design and drawings, providing final cost estimates to Raytheon and completion of volume 2 of the Phase III final report describing the Commercial Generating Unit.

CGU Boiler Design - The boiler design effort was completed.

Cost Estimation - The boiler island cost for both the conventional $2400 \mathrm{psi} 1000^{\circ} \mathrm{F} / 1000^{\circ} \mathrm{F}$ and LEBS designs were completed and provided to Raytheon.

Plant Efficiency - Total plant auxiliary power was finalized with Raytheon and final net plant efficiency determined. 


\section{Balance of Plant Subsystem}

In order to develop an overall plant design and to evaluate plant efficiency and cost, B\&W subcontracted with Raytheon Engineers and Constructors of Denver, Colorado. Together a Phase I concept was developed that achieved the initial LEBS goal of $38 \%$ net plant efficiency. That design resulted in identification of a number of potential improvements to the turbine cycle and auxiliary equipment needed to meet the Phase II goal of $42 \%$ net plant efficiency.

\section{V.1 Summary of Activities}

\section{V.1.1 Period of April 1997 through June 1997}

All design, drafting and cost estimating work was completed. Essentially all of the Phase III Volume 2 report has been drafted for internal reviews.

Final plant arrangement and P\&ID drawings were completed. Balance of plant equipment costs were developed and the economic analysis for the total plant was completed. Auxiliary power requirements were completed and the net plant efficiency was established at $42.27 \%$. The cost analysis/evaluation section for Volume 2 of the Phase III final report was completed and submitted to B\&W completing all Raytheon deliverables.

\section{V.2 Key Accomplishments}

Plaint Arrangement - Plant layout drawings and P\&ID's were finalized, completed and submitted to $\mathrm{B} \& \mathrm{~W}$ for incorporation into the final reports.

Plant Costs - Balance of plant costs for the conventional and LEBS designs were completed and the cost analysis including levelized busbar costs were completed.

Net Plant Efficiency - The steam cycle heat and mass balances and auxiliary power summary were finalized and the final net plant efficiency is an outstanding $42.27 \%$.

Final Reporting - All Final report contributions were completed to B\&W's satisfaction and received for incorporation. 


\section{Controls \& Sensors Subsystem}

In order to maintain low stack emissions and optimum boiler performance throughout the operating range and lifetime of the LEBS, a state-of-the-art integrated control system must be developed. This control system must include new sensors as well as old sensors used in new ways. It must make sense out of the data provided while initiating or directing the operator to take appropriate action. The control system that will help assure that the LEBS will meet its stack emission, efficiency, availability, and cost of electricity goals.

The overall philosophy of the LEBS control system is to use conventional, state-of-the-art solutions to satisfy new control requirements. Existing sensors, hardware, and software are specified whenever possible and new measurements or advanced equipment are recommended for development only where necessary to assure the success of the project. The progress of the Controls \& Sensors Subsystem is contained in this report.

\section{VI.1 Summary of Activities}

\section{VI.1.1 Period of April 1997 through June 1997}

Final report writing was completed. In addition, the POC DCS was revised to incorporate the full complement of controls and sensors on both burner groups and to include additional interposing logic and control loops on the E-LIDS ${ }^{\mathrm{TM}}$ system to reduce operating manpower requirements.

\section{VI.2 Key Accomplishments}

POC Control System - The POC DCS was revised to incorporate the full complement of controls and sensors on both burner groups and to include additional interposing logic and control loops on the E-LIDSTM system to reduce operating manpower requirements.

Final Reporting - All contributions by the Controls and Sensors subsystem for the Phases II and III final reports were completed. 